of the Jews: Origin and Development of Mystical Anti-Semitism [New York: Fromm Intl., 1992; 190, 207; print]). Suicides at Guantánamo Bay may have died, similarly, according themselves the role of shahid ("revered holy martyr"), rewarded in consequence of their successful attacks against American soldiers, representatives of the "Great Satan" (David Cook and Olivia Allison, "Self-Sacrifice against the "Great Satan': Al Qa'ida and Martyrdom Operations"; Understanding and Addressing Suicide Attacks: The Faith and Politics of Martyrdom Operations; fwd. Edward P. Djerejian [Westport: Praeger Security Intl., 2007; 48-49; print]). This argument is neither sympathetic nor charitable, but it may not be unrealistic despite that suicide is a forbidden act in the Abrahamic religions. With the shock of suicide bombers in Iraq and elsewhere, Gordon should be empathetic toward and more discursive about the problem that Israelis have been facing for a long time.

$P M L A$ readers expect studied arguments in support of the author's introductory arguments, not polemics.

Irving Rothman

University of Houston

\section{Listening to Sound in Poetry}

\section{To THE EDITOR:}

I was happy to see the double article by Marjorie Perloff and Craig Dworkin, "The Sound of Poetry / The Poetry of Sound" (123.3 [2008]: 749-61), which extended, while it reviewed, the theme of the 2006 MLA convention. For me this was the most interesting and hopeful of a careerful of MLA conventions. It asked attendees to consider a central element of poetry, sound, to put what works too often like an axiom-sound, as Pope said, echoes sense-under the strong light of contention, description, analysis, and discussion. The Presidential Forum and this subsequent double article remind us that sound can act independently from poetic meaning and may make a whole set of assumptions about poetry fall one after the other like dominoes. These assumptions include those that state categorically: a poem equals a lyric; a poem is primarily about the drama of the speaker or lyric subject and consequently "internalizes" the world; and (in one of the basic tenets of the academic and school accounts of poetry) a poem is primarily an act of communication.

The kinds of questioning that the main sessions of this forum encouraged emanated from, among others, poets and artists whose work explicitly questions the givens of poetic form and language. Participants included Susan Howe, Johanna Drucker, Charles Bernstein, and Kenneth Goldsmith. The forum, in other words, examined its topic with the help (predominant though not exclusive) of poets (as opposed to scholar/critics) and experimentalists. Primary attention rested on the poem, often from the perspective of practitioners of the art, so that the intellectual encounter with the subject was most memorably, for me at least, mediated, and thus authenticated, through the writerly.

Toward the end of his essay, Dworkin turns his attention to the venerable linkage between poetry and music, but he unsettles that connection by observing that in the twentieth century "music" itself has changed, no longer meaning "merely euphonious language, a mid-nineteenth-century sense of harmony and melodic line that 'delights the ear" but including twentieth-century workings by the likes of György Ligeti, John Cage, John Zorn, and Iannis Xenakis: "The idea of music in this expanded field ... may be a productive tool for understanding poetry and for thinking in new ways about what poetry might aspire to do" (759). We can take this comment further to our purpose by observing that art on the cutting edge, art that exists in part to test the borders of the too familiar, can itself propose a renewed sense of poetic function and method, often in a language close to the intersection of concept and practice and therefore all the more useful. And as one doesn't, in the twenty-first century, study the physical world through the instrumentalities of Newton, shouldn't we use the most advanced thinking about poetry to best understand it today? We have, in other words, just begun to explore the nature of sound in poetry. 
Scholarly criticism of poetry often impoverishes itself and our students by approaching poetry with outworn (usually nineteenth-century and early-high-modernist) definitions and assumptions. It is thrilling to see the MLA and $P M L A$, central official organs of the field, mod- eling a more inventive, intellectually challenging yet playful, and more inclusive attitude toward the great art of poetry. Will the rest of us take up the challenge?

Jeffrey C. Robinson University of Colorado, Boulder 